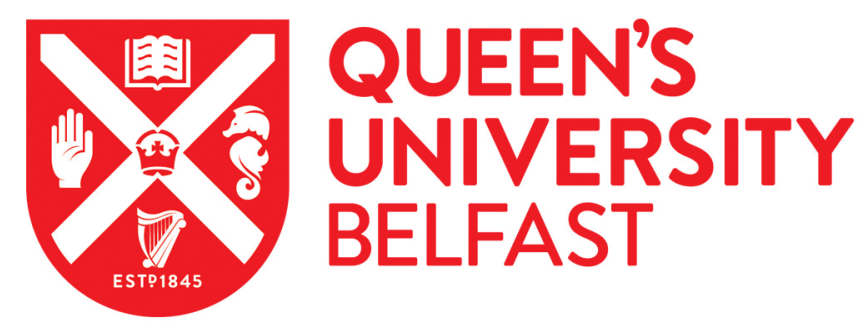

\title{
Learning Not to Curse: Swearing, Testimony, and Truth in Olaudah Equiano's The Interesting Narrative
}

Regan, S. (2013). Learning Not to Curse: Swearing, Testimony, and Truth in Olaudah Equiano's The Interesting Narrative. Eighteenth Century: Theory and Interpretation, 54(3), 339-357.

Published in:

Eighteenth Century: Theory and Interpretation

Document Version:

Publisher's PDF, also known as Version of record

Queen's University Belfast - Research Portal:

Link to publication record in Queen's University Belfast Research Portal

\section{Publisher rights}

C) 2013 University of Pennsylvania Press

All rights reserved. Except for brief quotations used for purposes of scholarly citation, none of this work may be reproduced in any form by any means without written permission from the publisher. For information address the University of Pennsylvania Press, 3905 Spruce Street Philadelphia, Pennsylvania 19104-4112

\section{General rights}

Copyright for the publications made accessible via the Queen's University Belfast Research Portal is retained by the author(s) and / or other copyright owners and it is a condition of accessing these publications that users recognise and abide by the legal requirements associated with these rights.

Take down policy

The Research Portal is Queen's institutional repository that provides access to Queen's research output. Every effort has been made to ensure that content in the Research Portal does not infringe any person's rights, or applicable UK laws. If you discover content in the Research Portal that you believe breaches copyright or violates any law, please contact openaccess@qub.ac.uk. 


\section{PROJECT MUSE*}

\section{Learning Not to Curse: Swearing, Testimony, and Truth in Olaudah}

Equiano's The Interesting Narrative

Shaun Regan

The Eighteenth Century, Volume 54, Number 3, Fall 2013, pp. 339-357 (Article)

Published by University of Pennsylvania Press

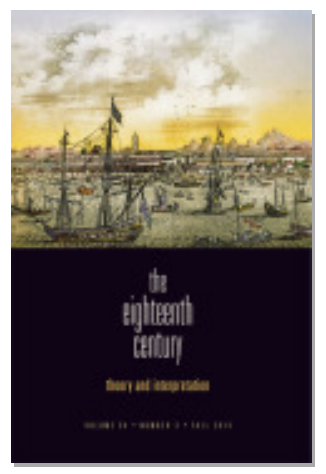

$\Rightarrow$ For additional information about this article http://muse.jhu.edu/journals/ecy/summary/v054/54.3.regan.html 


\title{
Learning Not to Curse: Swearing, Testimony, and Truth in Olaudah Equiano's The Interesting Narrative
}

\author{
Shaun Regan \\ Queen's University, Belfast
}

\begin{abstract}
You taught me language, and my profit on't
Is I know how to curse. The red plague rid you

For learning me your language!

-William Shakespeare, The Tempest, 1.2.362-64 ${ }^{1}$
\end{abstract}

My employer, unhappy for himself as well as others, was as horrible a swearer as I ever met with ... I was resolved to reprove my master when a proper opportunity offered. I said to him, "Dear sir, don't you know that the Lord hath declared, that he will not hold them guiltless who take his Name in vain? And that all profane swearers shall have their portion in the lake that burneth with fire and brimstone?" -Memoirs of the Life of Boston King, a Black Preacher. Written by Himself $(1798)^{2}$

In the Narrative of his life (1772), the second known example of the Anglophone (ex)slave narrative, Ukawsaw Gronniosaw describes the early stages in his acquisition of the English language. Decked out in servant's livery in the New York home of his master, Vanhorn, Gronniosaw recalls that although he occupied a "very easy place" in the house, "the servants us'd to curse and swear surprizingly; which I learnt faster than any thing, 'twas almost the first English I could speak." It was not long, however, before Gronniosaw was persuaded to desist from such profane usage of his recently acquired tongue, a change occasioned by the "correction" of an "old black servant," Old Ned, who informed him that "there was a wicked man call'd the Devil, that liv'd in hell, and would take all who said these words, and put them in the fire, and burn them." As Gronniosaw confesses, "This terrified me greatly, and I was entirely broke of swearing." ${ }^{3}$ 
The swift correction of his English tongue that Gronniosaw describes here provides a compelling contrast, if not a corrective, to Shakespeare's depiction of Caliban, the literary ur-figure in the West of slavish savagery and a creature who, apparently lacking any language of his own, profits from his master's tongue only through a new ability to curse both his master and himself. ${ }^{4}$ As Henry Louis Gates notes in relation to Gronniosaw's linguistic reversal, "if Gronniosaw, like Caliban, first learned the master's tongue to curse and swear, he quickly mended his ways. ${ }^{5}$ Significantly, though, Gronniosaw does not only relinquish swearing himself, he also endeavors to amend the tongues of others. Whereas previously he would "call upon God to damn" any servant who affronted him, he is soon rebuking his mistress (Vanhorn's wife) for calling upon God to damn her maid. ${ }^{6}$ Having learnt both how to curse and how not to curse, Gronniosaw sets about "learning" (i.e., teaching) others not to curse. ${ }^{7}$ Following hard upon his account of how a book (either the Bible or a prayer-book) owned by his previous master had refused to speak to him, this tale of the young slave's learning, unlearning, and "learning" regarding cursing and swearing is thus freighted with significance in terms of not only his own spiritual progress, but of the possible avenues by which Africans uprooted to the Americas via the Atlantic slave trade might set about making "profit" —or what we might now call "cultural capital" —out of their new masters' language.

Gronniosaw's concern with both falling into and forswearing cursing would also inform a number of other autobiographical writings and (ex)slave narratives published by black authors during the succeeding half-century, in which men such as Boston King and John Jea would record not just their own rejection of swearing, but how they set themselves up as linguistic and spiritual authorities by "learning" others a purified version of the English language. This double process, of invoking and disavowing profane cursing and swearing, is most fully developed in Olaudah Equiano's The Interesting Narrative (1789)—the longest and most complex work in the early canon of black Anglophone writing. In a manner that has been insufficiently registered in previous criticism, profane swearing plays a central role within The Interesting Narrative as spiritual autobiography. As his repeated criticisms of the "oaths" and "execrations" of sailors and slavers indicate, Equiano exhibits considerable interest in the verbal transgression and sin of swearing. More particularly, during the course of his life-story Equiano will both admit to his own profane lapses and represent himself intervening against other swearers-as when he tells his fellow shipmates

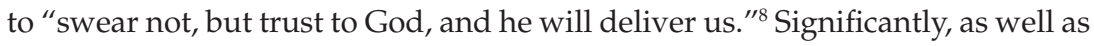
constituting a form of spiritual confession that might atone for such transgressions, Equiano's relation of his own lapses into swearing advances the Narrative's testimony to the earthly punishment of sinners. Indeed, one of the most striking features of The Interesting Narrative as spiritual autobiography is the specificity with which Equiano's testimony to the vengeful (as opposed to the beneficent) workings of Providence relates to such acts of profane enunciation. 
Besides a late indication that a heavy bout of rain may have constituted a punishment for breaking the Sabbath (210), in fact, the instances of God's retributive intervention into human affairs that Equiano explicates as such invariably represent responses to profane swearing - to moments at which Equiano and others take in vain either the name of God, or things pertaining to God. ${ }^{9}$

In order to account for this recurring concern with irreligious abuses of speech, and with the intersection between oaths and divine vengeance, I read the Narrative here alongside the eighteenth-century discourse against profane swearing and cursing, particularly as it was developed in the large body of sermons published (and, in many cases, frequently reprinted) from the later seventeenth century onwards. Examining the Narrative through this contemporaneous discourse can help to resolve some of the difficulties that critics have encountered in understanding Equiano's relation to swearing-not least the seemingly self-abjectifying way in which he casts his own profane oaths as sinful acts that elicit (and, perhaps, justify) divine punishment in the form of slavery and racial oppression. ${ }^{10}$ As contemporary discussions of the topic reveal, during the eighteenth century "profane swearing" was conceived as encompassing a range of verbal/religious transgressions, incorporating various kinds of curses and oaths along, sometimes, with the otherwise distinct notion of blasphemy. ${ }^{11}$ In a social context, of course, swearing, being "low and indelicate," a "notorious Breach of Civility and good Manners," and a sure "Sign of a Person's having kept low and vulgar Company," was contrary to the codes of behavioral decorum that, ideally, governed genteel status. ${ }^{12}$ From a theological viewpoint, acts of profane swearing also placed the loose of tongue in great spiritual peril. One of the principal source-texts for sermons on the topic was the Third Commandment, established within the Mosaic law in the Book of Exodus: "Thou shalt not take the name of the Lord thy God in vaine: for the Lord will not holde him guiltlesse, that taketh his Name in vaine" (Exodus 20:7). Importantly, this was the Commandment that, in itself, most explicitly attested that its transgressors would not go unpunished. As eighteenth-century writers on swearing emphasized, the Third Commandment had a "peculiar threatning annex'd to it," a "severe Threat" against its offenders. ${ }^{13}$ Throughout the century, from the pulpit and in print, Protestant clergymen continued to insist that God would both avenge himself upon the speakers of false oaths, and turn men's damnations upon themselves.

As various commentators also argued, common and profane swearing was intimately related to judicial oath-taking — the "legal procedure of calling down a curse upon oneself if one should deviate from what one has sworn to do or not to do," in Ashley Montagu's definition. ${ }^{14}$ The key source-texts in this regard were Matthew 5:34-37-Christ's admonition, during the Sermon on the Mount, to "Swear not at all . . . But let your communication be Yea, yea; Nay, nay" —and the related passage in James, 5:12: "swear not, neither by heaven, neither by the earth, neither by any other oath; but let your yea be yea; and 
nay, nay; lest ye fall into condemnation." Much of the discourse concerning swearing during the later seventeenth and eighteenth centuries was taken up with glossing these words, which might easily appear to forbid swearing of any kind. Against this literal reading, which was associated with the Quakers (the Religious Society of Friends), many divines went to considerable lengths to establish the validity of judicial oath-taking, in a fallen world in which men evidently did not always speak plain truth in all of their communications. ${ }^{15}$ While the taking of oaths ideally provided a guarantee of truthful testimony in a court of law, though, the use of profane language in everyday speech, it was claimed, threatened to compromise this process, so that common and profane swearing was also regarded as encouraging perjury. As the clergyman Francis Fox asked: "what Testimony can be depended upon, if Oaths become vile and contemptible by the common and unnecessary Use of them?" By removing the "Dread and Reverence which Men ought to have for Oaths" and habituating them to profaneness, common swearing thus undermined men's reliability as witnesses. By extension, such irreverent speech also posed a threat to the social fabric - given that, as one divine put it, "the whole order of the world" turned upon the truthfulness of legal testimony. ${ }^{16}$

The "world" invoked here was that of the free, white Briton. In stark contrast to this was the situation of slaves in the British colonies, whose own testimony was not legally admissible in relation to free persons (either for or against them). This statutory discrimination reflected the fact that, as E. V. Goveia notes, colonial slave laws were "made directly by the slave-owning ruling class" who regarded slaves principally as property. Within the British colonies, slaves were thus legally denied both subjecthood as persons and a voice with which they might appeal against their oppressors. ${ }^{17}$ In The Interesting Narrative and in his letters, Equiano repeatedly drew attention to this legalized discrimination in the colonies, which also bore upon the testimony of free blacks. As he recalls in the Narrative, for instance, even as white slavers swore and blasphemed around him, Equiano himself could have no redress against any ill-treatment received from such ungodly men: as “throughout the West Indies no black man's testimony is admitted, on any occasion, against any white person whatever . . . my own oath would have been of no use" (162)..$^{18}$ It was this injustice above all that registered with John Wesley, who noted that, in reading the Narrative, he was "particularly struck by that circumstance, that a man who has a black skin, being wronged or outraged by a white man, can have no redress; it being a law in all our Colonies that the oath of a black against a white goes for nothing." As the appalled Wesley exclaimed: "What villany is this!"19

The Interesting Narrative is haunted by the villainous invalidation of the slave's oath, and silencing of black testimony against oppression, in the British colonies. For Equiano, the interrelated issues of profane swearing and judicial oath-taking were crucially important both to his spiritual condition and to his claim, as a former slave, to truthful discourse and valid testimony. From a spiri- 
tual perspective, profane swearing constituted an abuse not just of words but of the Word-the living voice of God, the guarantor of truth and meaning. In inscribing his own discourse against swearing within the narrative of his life, Equiano thus asserted his own credibility and followed the injunctions of men such as the New England pastor, Nathaniel Appleton, who had preached of the need for believers to take personal responsibility for "suppressing this detestable vice" by acting as "ear witnesses of horrible profaneness" and bearing "due testimony" against it. ${ }^{20}$ Beyond its significance to his spiritual progress, this discourse against swearing also possessed implications for Equiano's immediate abolitionist purposes in the Narrative-a text principally concerned with testifying against whites' treatment of blacks in the colonies, from the perspective of a witness whose testimony would have been inadmissible in the colonies themselves. Equiano's critique of profane swearing represented an implicit (re-)claiming of status through language; a rejection of the disqualification of his oath that he had experienced as a slave. Part of the attraction of swearing as a narrative subject, moreover, may have been precisely the opportunities that it offered for presenting snapshots of an actively retributive deity, thereby strengthening the stark warning that Equiano, like Ottobah Cugoano before him, was laying before the public: that the barbarities associated with West Indian slavery would "bring down God's judgment on the islands" (108). ${ }^{21}$ To secure the credibility of his textual testimony to the iniquities of the "accursed trade" in slaves (59), Equiano thus worked to purify his oath by disavowing the profane and common swearing that might jeopardize his witnessing, in a process that bound swearing and slavery together via the invocation of a vengeful God.

The first allusion to swearing in The Interesting Narrative occurs in the opening chapter, in which Equiano describes the manners and customs of his Igbo ancestors. As the narrator recalls:

I remember we never polluted the name of the object of our adoration; on the contrary, it was always mentioned with the greatest reverence; and we were totally unacquainted with swearing, and all those terms of abuse and reproach which find the way so readily and copiously into the languages of more civilized people. The only expressions of that kind I remember were "May you rot, or may you swell, or may a beast take you." (41)

In line with his overall treatment of his native people in this chapter, the verbal rectitude of the Igbo with regard to both their "Creator" and each other is read by Equiano through the (Western, anthropological) paradigm of the primitive purity of African society. Here, as elsewhere, Equiano implicitly argued that a 
culture of pre-civilized "simplicity" could provide a more secure foundation for the enactment of Christian principles than a culture which, while nominally civilized and Christian, in many respects had veered into a luxurious, and profane, degeneracy. ${ }^{22}$ Intriguingly, this passage represents one of the instances at which the narrative particularity of Equiano's writing partly works against its ostensible design. Despite his initial claim that the Igbo are "totally unacquainted with swearing," Equiano here actually allocates a greater variety of curses to the Igbo than he will directly attribute to "civilized" (Western or Europeanized) people during the Narrative as a whole. More significant, in terms of his concern with the uses and abuses of names and words, is the immediate context of Equiano's testament to the Igbo's spiritual reverence and interpersonal decorum with regard to language. For, this passage immediately succeeds the more frequently remarked sentence in which Equiano posits an Igbo etymology for his native name: "I was named Olaudah, which, in our language, signifies vicissitude, or fortunate also; one favoured, and having a loud voice and well spoken" (41). In itself, this possibly erroneous, and undeniably over-determined etymology combines tinges and portents of Equiano's divine election, his worldly travails, and both the power and the integrity of his voice. Situated in apposition to his account of the Igbo's unpolluted and unpolluting tongue, the reader might also justifiably surmise that Equiano's fortunate and well-spoken nature partly constitutes a cultural inheritance from the Igbo-a people who, in theory at least, are "totally unacquainted with swearing." ${ }^{23}$

As this early account of the Igbo forebodes, Equiano will testify on numerous occasions to the profane discourse of supposedly "civilized" white men. Particularly in the chapters that deal with his experiences in the Caribbean, such language frequently accompanies and anticipates physical maltreatment, threats, and impositions, simultaneously advertising and augmenting other forms of uncivilized barbarity. When, in St. Croix ("Santa Cruz"), two white men snatch the goods of the enslaved Equiano and his companion, for instance, their initial swearing leads inexorably to a threat of flogging; upon complaining to the commanding officer of the fort, they are received not only with "a volley of imprecations" but also with the further threat of physical chastisement with a horse-whip (117-18). In these narrative attestations to the oxymorons of Christian profanity and civilized "abuse," Equiano can be viewed as expanding upon Gronniosaw's Narrative. Further to his early acquirement and subsequent rejection of cursing and swearing, Gronniosaw had gone on to express astonishment at hearing the inhabitants of Plymouth—in the "Christian Land" of England-“"curse and swear, and otherwise profane." In Gronniosaw's own Narrative, such profaners had apparently avoided the fates suffered by those other "enemies of the LORD" (and oppressors of Gronniosaw himself), who had been "cut off" from life by "a very awful Providence."24 In other spiritual works, however, these interests in swearing and divine retribution were often combined, in anecdotal accounts of Providential punishments being meted 
out to profane swearers specifically. From William Bradford's famous account of the "proud and very profane yonge man" aboard the Mayflower, whose "curses light on his owne head," to examples in works by Bunyan, John Flavel, Jea, and others, readers of spiritual literature received periodic reminders of the potentially grave consequences of speaking lightly of the divine. ${ }^{25}$

In The Interesting Narrative itself, such intermittent testimony to God's active punishment of profane swearers is taken a stage further, so as to constitute, within Equiano's text, an important Providential and narrative pattern. The first direct evidence that Equiano provides of God's retributive intervention into worldly affairs involves an incident that takes place in 1757 on board the man of war the Preston, of which Equiano's master, Michael Henry Pascal, had just been made first lieutenant:

While I was in this ship an incident happened, which though trifling, I beg leave to relate, as I could not help taking particular notice of it, and considering it then as a judgment of God. One morning a young man was looking up to the fore-top, and in a wicked tone, common on shipboard, $\mathrm{d}-\mathrm{d}$ his eyes about something. Just at the moment some small particles of dirt fell into his left eye, and by the evening it was very much inflamed. The next day it grew worse; and within six or seven days he lost it. (72)

With this anecdote of a sailor blinded in one eye, Equiano instigated a form of Providential reading that recurs throughout the Narrative, in which acts of divine judgment are cast in terms of the lex talionis, or "law of retaliation": a law associated with the Old, Hebraic (rather than with the New, Christian) Testament, and which, in the Narrative itself, had already been presented as the principle upon which, among the Igbo, disputes were decided and crimes punished $(33,44)$. As Equiano suggests: while, in a certain light, a single instance of swearing of this kind might be viewed as unremarkable, it is nevertheless sufficiently serious to bring about a chastising "judgment of God."

With his reading of this incident, Equiano commenced the textual earwitnessing to profane swearing that would function to distance his own testimony from such irreverent enunciation. The Narrative's rendition of the moment as a demonstration of divine retribution is very much in tune with the rhetoric employed in the contemporary discourse against swearing. As James Stonhouse noted in his Admonitions against Swearing, Sabbath-Breaking, and Drunkenness, "The Swearer is trifling in the grossest Manner with the most tremendous of all Beings." As Stonhouse had gone on to warn his readers, therefore:

Consider how dreadful would be your State, if God, when thus provoked and defy'd, should inflict on you that Damnation, which you so unnaturally wish for yourselves, or wantonly and cruelly imprecate on others; and so "your own Tongue fall on you," Psalm lxiv.8. ${ }^{26}$ 
Stonhouse's words here usefully pinpoint the underlying principle of Equiano's anecdote of the blinded sailor. With this treatment of the young man's "exclamatory" or "ejaculatory" oath, God in effect avenges himself upon those who assume-and, in so doing, profane-the divine prerogative of damnation. ${ }^{27}$ As Stonhouse suggests, such presumptuous parodies of divine power are liable to be punished in their own terms; as retribution for mimicking His power, God will simply allow the profane wish to be performed. ${ }^{28}$ In the episode on board the Preston, we might note, this ironic enactment of an ungodly damnation is especially barbed. For, in what could itself be viewed as a profane parody of his own principle, God here literally retaliates upon the sailor's spiritual blindness with "an eye for an eye" —or, more precisely, with an eye for the presumptive damning of an eye.

As noted earlier, during the Interesting Narrative as a whole Equiano's testaments to such divine enactments of the "law of retaliation" will be related almost exclusively to acts of profane swearing. Given the amount of time that he spends in the company of sailors, who were notorious for their irreligious idiom, it is perhaps unsurprising that Equiano himself eventually succumbs to swearing. ${ }^{29}$ Significantly, a number of key episodes and turning points in the Narrative revolve around the profane lapses to which Equiano himself confesses in the service of his spiritual, and abolitionist, witnessing. The first personal admission to such lapses occurs when, endeavoring to account for lieutenant Pascal's monumental ingratitude in selling him back into slavery towards the end of the Seven Years' War, the religiously-minded Equiano reflects upon his conduct with regard to God:

I recollected that on the morning of our arrival at Deptford I had rashly sworn that as soon as we reached London I would spend the day in rambling and sport. My conscience smote me for this unguarded expression: I felt that the Lord was able to disappoint me in all things, and immediately considered my present situation as a judgment of Heaven on account of my presumption in swearing: I therefore, with contrition of heart, acknowledged my transgression to God. (95)

Developing his textual entanglement of swearing and divine retribution, what Equiano suggests here is that, in return for a mildly presumptive verbal lapse, God consigns him to several years of West Indian slavery. In terms of the Providential pattern that Equiano reads into his life, it is perhaps fitting that it should be his presumption in swearing - a sign of his spiritual imperfection and slavery to sin-that enables his subsequent testimony regarding the brutal system of plantation slavery. In a demonstration of almost cruel (divine) logic, Equiano the swearing sinner is led, via enslavement, to become a key witness against the crying sin of slavery itself.

The apparent disproportion between cause and effect implied in Equiano's interpretation of the consequences of his "unguarded expression" at Deptford 
has proven hard for some modern critics to take. For Douglas Anderson, for instance, Equiano's reading of Pascal's selling him into slavery as "a judgement of Heaven" for swearing constitutes "a ludicrous application of providentialist thinking." ${ }^{\prime 30}$ In a considered discussion of "religious authority" in the Narrative, Eileen Elrod also finds the passage "perplexing," pointing to the seemingly contradictory process whereby Equiano "condemns himself for the imperfections of his piety at the same time [that] he records the horrific violence of slavemasters." Revealingly, though, what Elrod finds problematic here is not simply the disjunction between the crimes of Equiano and his slavemasters but also, on Equiano's part, a sense of "piety" that Elrod describes as "narrowly defined," and a code of virtue which she feels can only appear, "to contemporary readers," as "peculiarly personal." ${ }^{11}$

A remedy for such critical perplexity is to be found in the eighteenth-century discourse against profane swearing. As was frequently noted, one of the reasons for the particular focus upon the sin of swearing was the ease with which it could be both committed and repeated. This was a serious theological problem because, as the Reverend Henry Peckwell would remind Equiano himself (187), whoever offended in one point of God's law would be "esteemed in the Sight of God, as Guilty of transgressing All the Law" (James 2:10).32 Furthermore, as the author of A Letter to a Prophane Person (1721) put it, with each oath uttered the profaner threw "so many Faggots more into the Eternal Flames" that awaited him. ${ }^{33}$ It was largely on account of this recognition of the ease with which one might sink into swearing that contemporary sermons veered close to presenting such transgressions as the worst of all sins, or actually made this very claim. Enlarging upon the "Aggravations" of the sin in a frequently reprinted sermon on the topic, for instance, Edmund Gibson, the Bishop of London, had proclaimed that "common Swearers" were "more wicked and inexcusable than any other Sinners whatsoever." ${ }^{\prime 34}$ Such sentiments at least partly explain Equiano's own, particular concern with swearing in the Interesting Narrative, and with what he represents as the reality of the divine punishment of profane sinners. This is particularly striking given the work's status as an extended, non-sermonic prose narrative. A simple contrast here is provided by a clutch of comic novels published during the period with which the Narrative deals. Despite being written by Anglican vicars, works such as Laurence Sterne's Tristram Shandy (1759-67) and Richard Graves's The Spiritual Quixote (1773) had subverted reformational and evangelical strictures against swearing by satirically re-articulating profane execrations through the mouths of the novels' Catholic and Methodist targets. Set beside such writings, Equiano's Narrative can justifiably be viewed as a work of didacticism; which, far from jesting upon or even simply reflecting common swearing, actively illustrated the profound spiritual consequences of such verbal slips. To this extent, The Interesting Narrative aligned itself with the reforming societies-the Society for the Reformation of Manners and the Society for the Promotion of Christian 
Knowledge-whose values had helped to generate, and which in some cases authorized the publication of, the many sermons against swearing that were published during this period. ${ }^{35}$

To Equiano himself, then, the punishment that he suffers for his profane lapse at Deptford may not have seemed as disproportionate as it is liable to appear to modern readers. As he describes them in the second half of the Narrative, however, some of the further instances of profanity and oral presumption into which Equiano falls are, theologically speaking, more problematic. At the beginning of Chapter 8, for instance, the now-free Equiano narrates how the ship upon which he was serving - the sloop, and slave carrier, the Nancy-became wrecked upon a bank of rocks in the Bahamas. The importance that Equiano himself attached to this episode is revealed by a textual apparatus of frontispiece illustration and Biblical epigraphs which both portrayed, and read spiritual significance into, the wrecking of the ship. ${ }^{36}$ Significantly, the episode that Equiano prepares for so carefully here is another key moment that turns upon an act of profane swearing. During the ship's journey to Georgia, Equiano has twice had a portentous dream. As he puts it: "I dreamt the ship was wrecked amidst the surf and rocks, and that I was the means of saving every one on board." Later the second night, while on his watch, he unwisely proceeds to express his impatience at the ship's lack of progress with an exclamatory oath, "Damn the vessel's bottom out," after which he experiences the dream a third time (148). As in the episode of the blinded sailor, Equiano's oath is now literally enacted as, that same night, the ship becomes caught upon the rocks. Once again, Equiano is forced to ponder the apparently intimate connection between his profane swearing and his misfortunes:

In a moment a scene of horror presented itself to my mind, such as I never had conceived or experienced before. All my sins stared me in the face; and especially I thought that God had hurled his direful vengeance on my guilty head for cursing the vessel on which my life depended ... I determined if I should still be saved, that I would never swear again. (149)

While, as Tony McEnery argues, the word "damn" gradually "fell out of use," so that "over the [eighteenth] century its potency was lost," we again witness Equiano here operating according to an earlier paradigm. ${ }^{37}$ As his Bahamian adventure confirms, in the eighteenth-century world of The Interesting Narrative "damns" not only remained freely in use, they also retained their (spiritual) potency as irreverent enunciations that were susceptible to immediate punishment by God.

While Equiano-along with the rest of the crew and the "live cargo" of 
slaves (133) - is thus chastised for his profane oath, by contrast with the earlier episodes of this kind the wrecking of the Nancy also appears to provide Equiano with an instant opportunity to atone for his transgression. In a development that encapsulates what S. E. Ogude has termed the "insistent note of self-dramatization and self-approval" in the Narrative's portrayal of its "central actor-character," Equiano, aided by three black men and a Dutch creole sailor, heroically ensures the preservation of all of the men on board, even as most of those around him are succumbing to the physical and spiritual perils of drink and despair. ${ }^{38}$ As Equiano proudly recalls, once everyone is safely on shore he becomes "a kind of chieftain amongst them" (151). Arguably, however, Equiano's heroic self-fashioning here is at odds with the moral and theological lesson implied in the divine punishment itself. For, as Equiano also notes upon recalling the dream that had portended the shipwreck, "I could not help looking on myself as the principal instrument in effecting our deliverance" (151). As this declaration suggests, from the author's own perspective the paradoxical implication of the episode in the Bahamas is that, having transgressed against God by profanely appropriating the divine power of damnation, Equiano is subsequently able to make spiritual atonement by assuming the Christ-like role of redeemer or savior.

More problematic again is Equiano's account of his dealings along the Mosquito coast, where he helped his friend, Charles Irving, to establish a slave plantation. When an inebriated Indian governor sparks off a "great commotion" among the people, Equiano reports, he copies a ruse of Columbus's in order to quell the riot. Pointing at the heavens, he says,

I told them God lived there, and that he was angry with them, and they must not quarrel so; that they were all brothers, and if they did not leave off, and go away quietly, I would take the book (pointing to the bible), read, and tell God to make them dead. This was something like magic. (208)

While not, perhaps, strictly speaking an act of profane swearing, Equiano's ruse is usefully viewed in the light of his earlier verbal transgressions. In this episode, Equiano again appears to impinge upon the boundary between himself and his Maker. Rather than simply communicating with God, what Equiano posits here is a mastering of God; a speaking at God for the purposes of commanding Him. In relation to profane swearing specifically, Equiano's threatening of the Miskito Indians can be read as a doubled transgression. Like his profane lapse at Deptford, Equiano's verbal threat involves a presumption of his ability to direct events himself. That he invokes the Bible as the medium of this threat also veers the scene towards a parody of judicial oath-taking, which travesties the court-room use of the Bible to appeal to God's witness to truth. Within the terms of the contemporary discourse concerning swearing and cursing, it is thus Equiano himself, rather than the Indians, who risks a divine pun- 
ishment here, both for taking the Lord's name in vain and for presuming to promise actions, and acts of vengeance, that only God might truly direct. ${ }^{39}$

Even if we regard it as involving a mere dabbling with or feigning of the notion of assuming God's punitive power, Equiano's "biblical" encounter with the Miskito nevertheless retains an air of sacrilege, insofar as it situates him once more as the agent of the divine. That Equiano should refer to his ruse as "something like magic," of course, hardly helps to contain the episode within a Christian framework. Recalling his description of the "Ah-affoe-way-cah," the Igbo priests and magicians (42), this invocation of magic may constitute another of Equiano's attempts to reconcile African rituals and belief systems with those of his new English religion. If, as Walter Pitts suggests, "The Anglican Church had rationalized the animistic 'magic' out of religion," then Equiano can be viewed here as gesturing towards reanimating this "magic," in a more broadly Christian context. ${ }^{40}$ Arguably, however, this invocation of magic speaks equally to the difficulties that Equiano faced in reconciling his two cultures on the plane of religion, projecting as it does the idea of Christian magic, or of Equiano as a Christian magician. From the perspective of his new Church and beliefs, we might say, it is only through a profane (mis)use of the Bible-the book that tells "how all things had a beginning" (68)—-that Equiano is able to threaten the Indians with a bad end. ${ }^{41}$

Notwithstanding the sacrilegious overtones of this self-aggrandizing encounter with the Miskito, the fact that Equiano has now desisted from swearing, at least in its more easily recognizable forms, is attested by the Miskito prince, who notes that, of all the "white men" aboard ship, only Equiano does not "swear, lie, and get drunk" (204). ${ }^{42}$ This somewhat surprising designation of "The African" as a "white" man invites a broader consideration of swearing in relation to Equiano's cultural identity, and status as a witness, at the end of the Narrative. A suggestive starting-point here is the transformation that has taken place in Equiano's relation to the trope of the talking book. If, from among its prior appearances in the tradition of black autobiographical writing, Equiano's employment of this trope earlier in the Narrative had been most reminiscent of Gronniosaw's, then his refiguration of it in the Miskito episode more closely resembles its appearance in John Marrant's A Narrative of the Lord's Wonderful Dealings with John Marrant, A Black (1785). As Gates has shown, in that work Marrant had inverted Gronniosaw's account of how his master's book refused to speak to him, so that, in Marrant's own encounter with Amerindians, "it is only the black man who can make the text speak." Reinscribing (if not reversing) his relation to racial difference, in his Narrative Marrant had thus amounted to "a substituted white man in the presence of the Cherokee." 43 For his account of his time among the Miskito, Equiano himself appears to have drawn upon 
Thomas Wilson's An Essay Towards an Instruction for the Indians (1740)—a work of popular piety that Equiano received at his baptism and which, along with the Bible, was one of "the two books I loved above all others" $(78,119)$. Intriguingly, Wilson's work provides a suggestive analogue (and possible source) for the Miskito prince's critique of the white men who "swear, lie, and get drunk." As Wilson's inscribed Indian remarks, regarding his people's reservations about the Christian religion:

Are not the same Wickednesses seen amongst them, as amongst the worst of People?-They make no Conscience to cheat and defraud even one another;--and where they have Power, they oppress without Pity.-Whoredom and Drunkenness, and Falshood and Deceit, and Lying and Cursing, and Swearing and Calling upon the God they worship to plague each other, upon every foolish Occasion. ${ }^{44}$

In response to these reservations, Wilson's Missionary offers an observation that chimes only too resonantly with Equiano's own sentiments regarding merely "nominal" adherents to his new faith (61): "all are not Christians who go under that Name." 45 Indeed, as William Mottolese argues in a useful comparison of the two works, Equiano "increasingly characterizes himself in his narrative as an individual who more resembles Wilson's white Missionary, in terms of cultural and especially religious authority, than Wilson's Indian or the naïve slave that he once was." ${ }^{\prime 46}$ This is not least the case during his voyage from England to the Caribbean, when Equiano (albeit unsuccessfully) attempts the instruction, and spiritual conversion, of the Miskito prince himself. In this cross-cultural encounter, Equiano in effect moves from the passive position of being instructed by Wilson's text, to the active (and evangelical) position of seeking to spread the Word that it contains.

This comparative analysis between Equiano's and Wilson's texts is both supported and complicated by another book that Equiano also appears to have acquired (but which Mottolese overlooks): Laurence Harlow's The Conversion of an Indian (1774). ${ }^{47}$ In various ways, the critique of Christian life that is offered in this work similarly tallies with Equiano's own observations in The Interesting Narrative. During the course of his brief investigation into the Christians' God, the work's Indian narrator registers his preference for the lively evangelism of the Methodists over the staid homiletics (and inattentive congregations) of the regular Church; notes that while the "greatest part" of the men he sailed with to England were "distinguished by the name of Christians," they "often called upon God to damn their eyes, their hands, their feet, and their blood"; and contends that while many of his "poor fellow sinners" are likewise "distinguished by the name of Christians," they have "no more regard to the reality of this book [the Bible], than our poor slaves, who have never heard of its being in the world." Notably, in relation to profane swearing, Harlow's narrator also pointedly reverses the direction of the profanities that he hears upon every street 
in London, which he presents as reflecting unfavorably upon these white profaners of the divine and offering "a standing proof of the curse levelled upon Adam's rebellious race." ${ }^{\prime \prime 8}$

In line with Equiano's assertion that, along the Mosquito coast, he saw no white man "that was better or more pious than those unenlightened Indians" (206), the narrator's critique of nominal Christianity in The Conversion of an Indian - much of which is launched before the Indian's "conversion" - indicates that Equiano did not necessarily need either to view or to fashion himself as a "white Missionary" in order to set forward his own, similar critique. Nevertheless, as the analyses of Gates and Mottolese suggest, within The Interesting Narrative Equiano's encounter with the Miskito Indians both enacts and participates in a process of cultural reversal, whereby the former slave, who had been (perhaps mockingly) called "the black Christian" by his shipmates (92), adopts the behavior, and assumes the cultural position, of someone who is both a Christian teacher and, albeit in "substitute," a white man. Through this cultural (re-)positioning, Equiano distanced himself further from the legal exclusions suffered by blacks in the British colonies, asserting instead both his identity as a British Christian and the validity of his free black voice. Where Harlow's Indian had appropriated God's curse upon Adam's race for a critique of (white) modern Christians, Equiano may thus be said to have countered the enduring racial slur upon blacks that was known as the "curse of Ham." ${ }^{49}$

In The Interesting Narrative, Equiano's learning (or re-learning) not to curse, and the "learning" of others both involved and implied in this process, were important and necessary authorial gestures. Providing a firm foundation for his critique of the profane failings of merely "nominal" Christians, this narrative of spiritual improvement in relation to language itself functioned to bolster the authorial "authority" of the former slave turned "English" abolitionist (and, in various respects, imperialist). In a significant moment that occurs prior to his activities in Central America, and which is usefully read against the passage from Gronniosaw with which I began, Equiano relates how he seconded, "with some boldness," a young man who had reproved Richard Strange, captain of the Hope, for blaspheming "God's most holy name." With understandable surprise, given the chastisements he has previously received for talking "too much English" and "too good English" (94, 159), Equiano recalls how he "expected that the captain would be very angry with me for speaking, but he replied not a word" (200-201). While his alliance with a white man may well have contributed significantly to this lack of any come-back from the captain, Equiano can nonetheless be viewed here successfully admonishing a white profaner of the Lord's name. ${ }^{50}$

It is prior to this moment, during the lead-up to his spiritual rebirth in the 
mid-1770s, that, having "fervently begged that God would never again permit me to blaspheme his most holy name" (182), Equiano had finally managed to live up to his own earlier pledge, to "never swear again." Whereas during the spiritual crisis that precedes this period he had taken to blaspheming (181), he now becomes more actively concerned to avoid the company of swearers, anxious about catching the "horrible infection" where (as on shipboard) the "name of God" was "much blasphemed" (188). ${ }^{51}$ Noticeably, while Equiano's emphasis at this point in the Narrative is upon God's "spiritual mercy" and "grace" $(182,191)$, his salvation through Christ does not bring to a conclusion his narrative preoccupation with either swearing or divine vengeance. When, back in the Caribbean, the foul-mouthed sloop-owner Hughes has him hoisted up with ropes despite his protestations as a free man, Equiano remains as concerned about the "oaths and imprecations" of this "blasphemer" as he is about his own dangerous situation (211-12). Importantly, however, by the end of the Narrative Equiano himself has managed to recapture-albeit in a different language-the uncorrupted tongue that he had earlier attributed to his Igbo ancestors.

Mediating between verbal simplicity, spiritual improvement, and abolitionist witnessing, Equiano's recapturing of a plainness and purity of speech can be said to underpin what we might term the integrity of his authorial voice in the Narrative. As Nathaniel Appleton had noted, "A man who uses himself to swearing, will doubtless fall into a way of dissembling and deceit; so that at length there will be no dependance upon what he says, even altho' he should swear to it." ${ }^{\prime 52}$ In a broad sense, the rationale for Equiano's narrative critique of false and profane swearing and cursing was to secure the validity of his testimony against the "enormous cruelties" inflicted upon his "sable brethren" as part of the "cruel and unjust" traffic in slaves (5). The Interesting Narrative, Equiano intimated, was truthful, rather than false, witness. ${ }^{53} \mathrm{~A}$ further, related aspect of this deliverance from swearing concerns its social and cultural cachet. As Vincent Carretta has argued, in the Narrative Equiano laid claim to a gentlemanly status that was the English equivalent of the Igbo Embrenchéthe distinguished status for which, Equiano indicates, he had been destined in Africa. Significantly, as Carretta also notes, among his other characteristics a gentleman had been regarded historically as someone whose word was his bond (and from whom, consequently, no special oaths were required to support his credibility). ${ }^{54}$ As Equiano was all too aware, of course, while the word of a (white) British gentleman might be regarded as his bond, the same could not be said for most black men and women in the English-speaking world-not least those in the British colonies, who were denied recourse even to legal testimony against their white oppressors.

Through his narrative account of his struggle with and ultimate triumph over profane swearing, Equiano symbolically reasserted his oath. Such verbal recuperation was especially important because, as the Narrative continually demonstrates, men are only as good as their word. Not only is the ungodli- 
ness of many of the white slavers Equiano encounters attested from their own mouths but, as I have noted, these unholy testaments are themselves often accompanied by, if not inseparable from, physical acts of inhumanity. As Thomas Bradbury had suggested in The Sin and Danger of Profane Swearing, therefore, "it is undeniable, that he who has no Fear of an Oath, has no Fear of God." 55 For the authorial Equiano, by contrast, truth itself was intimately connected to (respect for) both the name and the Word of God. As for the author of An Earnest Invitation to all Profane Persons to Repent, then, for Equiano the unrepentant swearer could be regarded as, in essence, a "perjured Person." ${ }^{56}$ In The Interesting Narrative, bearing testimony to the brutalities of slavery thus necessitated an active disavowal of, and atonement for, the profane swearing that continually threatened to corrode Truth.

\section{NOTES}

1. William Shakespeare, The Tempest, ed. Stephen Orgel (Oxford, 1987), 1.2.362-64.

2. Boston King, "Memoirs of the Life of Boston King, a Black Preacher. Written by Himself, during his Residence at Kingswood-School" (1798), in Unchained Voices: An Anthology of Black Authors in the English-Speaking World of the Eighteenth Century, ed. Vincent Carretta (Lexington, 1996), 351-68, 361.

3. James Albert Ukawsaw Gronniosaw, "A Narrative of the Most Remarkable Particulars in the Life of James Albert Ukawsaw Gronniosaw, An African Prince, As Related by Himself" (1772), in Carretta, Unchained Voices, 32-58, 38-39.

4. In the section of the play in which these lines occur, Caliban-who, according to Prospero, only "stripes [i.e., lashes] may move" - is referred to as "slave" on six occasions (Shakespeare, The Tempest, 1.2.308-73). In his discussion of The Tempest in relation to "linguistic colonialism" during the early modern period, Stephen Greenblatt usefully compares Columbus's insinuation that the inhabitants of the New World themselves possessed "no language at all" (Learning to Curse: Essays in Early Modern Culture [New York, 1990], 17).

5. Henry Louis Gates, Jr., The Signifying Monkey: A Theory of African-American Literary Criticism (New York, 1988), 135.

6. Gronniosaw, 39.

7. See the second definition of "To LEARN" ("2. To teach") in Samuel Johnson's A Dictionary of the English Language, 2 vols. (London, 1755). Notoriously, in the quotation from The Tempest that he used to illustrate this meaning, Johnson altered Caliban's protest to "I know not how to curse."

8. Olaudah Equiano, The Interesting Narrative and Other Writings, ed. Carretta (New York, 1995; repr. 2003), 158. Further references will be cited parenthetically in the text.

9. On The Interesting Narrative and spiritual autobiography more broadly, see Adam Potkay, "Olaudah Equiano and the Art of Spiritual Autobiography," Eighteenth-Century Studies 27 (1994): 677-92.

10. For George Boulukos, for instance, Equiano in such instances "interprets the acts of individuals enforcing the regime of racial difference as providential acts of God," so that his emphasis upon his own sin of swearing represents a personal appropriation of the guilt of others and an obfuscation of the more horrifying, and less easily comprehensible, realities of "race as an institution" and of the "systematic exploitation of Africans" within the divine order of things (The Grateful Slave: The Emergence of Race in EighteenthCentury British and American Culture [Cambridge, 2008], 198-99). My aim is to account for Equiano's thinking here more precisely in relation to the eighteenth-century discourse concerning swearing. A few of the instances of swearing that I examine in this article are 
also considered in the introduction to an engaging discussion of the Narrative by Jesse M. Molesworth, within the broader category of "speech acts" ("Equiano's 'Loud Voice': Witnessing the Performance of The Interesting Narrative," Texas Studies in Literature and Language 48, no. 2 [2006]: 123-44). My own discussion focuses more directly and extensively on acts of profane swearing specifically, in the context of a sermonic discourse about swearing (and about divine punishment for swearing) that Molesworth does not address.

11. For the technical distinction between profanity and blasphemy, see Ashley Montagu, The Anatomy of Swearing (Philadelphia, 1967), 101-2. As in the Bible itself, however, during the eighteenth century it was possible to blaspheme the name of God (which is to swear profanely), as for instance when Equiano states that "I hated the house in which I lodged, because God's most holy name was blasphemed in it" (182). A further distinction can also be made between swearing and cursing, with the latter being "more malevolently intended" than the former (Montagu, 52).

12. The Connoisseur No. 108 (19 February 1756), 2 vols. (London, 1755-56), 2:652; James Stonhouse, Admonitions against Swearing, Sabbath-Breaking, and Drunkenness, Designed for the Benefit of such, as are Guilty of one, or more of these Vices, 8th ed. (London, 1774), 3-4; and Archbishop Sharp's Sermon on the Several Causes of Men's Mistakes about the Terms of their Salvation: and Archbishop Sharp's and Archbishop Secker's Sermons Against Perjury and Common Swearing, with some Alterations, to Make them better understood by Persons of all Ranks (Dublin, 1771), 27.

13. Samuel Wright, A Discourse against Profane Swearing, 2nd ed. (London, 1732), 19; Edward Wells, A Letter to a Friend, concerning the Great Sin of taking God's name in Vain. Whereunto are added, one or two Remarks concerning Vain or Common Swearing (London, 1769), 5.

14. Montagu, 59.

15. For the Quaker position, see for instance Joseph Phipps, All Swearing Prohibited Under the Gospel (London, 1784).

16. Francis Fox, The Lawfulness of Oaths, and the Sin of Perrjury [sic] and Profane Swearing (London, 1710), 26; Archbishop Sharp's Sermon, 23; Gilbert Burnet, Select Sermons (Glasgow, 1742), 48 .

17. E. V. Goveia, The West Indian Slave Laws of the 18th Century (Barbados, 1970), 19-20. As Goveia notes, while the evidence of slaves was not admitted in relation to free persons, it could be admitted for or against other slaves-a legal anomaly that only functioned to reinforce slaves' inferior status (34).

18. See also 122, 129-30, 212, and 218 (in the text itself); plus 331 (in a public letter to James Tobin, who had denied James Ramsay's similar claim regarding oaths in the colonies) and 358 (in a letter to the Rev. G. Walker).

19. John Wesley to William Wilberforce, February 1791, reprinted in The Interesting Narrative of the Life of Olaudah Equiano, or Gustavus Vassa, The African, Written by Himself, ed. Werner Sollors (New York, 2001), 281-82.

20. Nathaniel Appleton, A Plain and Faithful Testimony against that Abominable, but too Fashionable Vice of Profane Swearing (Boston, 1765), 49, 52.

21. Compare also 233 (in the text itself), plus 330-31 and 335 (in letters to the papers). See Quobna Ottobah Cugoano, Thoughts and Sentiments on the Evils of Slavery and other Writings, ed. Carretta (Harmondsworth, 1999), especially 76-79.

22. Equiano's irony regarding the polluted "languages" of "civilized people" was anticipated by the author of an "Ironical Sermon" upon swearing, who noted swearing's modern status as a "genteel accomplishment" (An Extract from An Ironical Sermon, wherein are shewn the Advantages, Pleasure, and Profit of Swearing in Common Conversation [London, 1784], 4).

23. I do not engage here with the controversy surrounding Equiano's birthplace, which has been provoked by Carretta's discovery of documents (a baptism record and a ship's muster book) which suggest that he may have been born in South Carolina, rather 
than (as Equiano claims in the Narrative) in the Benin region of what is now southern Nigeria. For the fullest account of Carretta's findings, see his Equiano, The African: Biography of a Self-made Man (Athens, Ga., 2005); in response, see especially Paul E. Lovejoy, "Autobiography and Memory: Gustavus Vassa, alias Olaudah Equiano, the African," Slavery and Abolition 27, no. 3 (2006): 317-47.

24. Gronniosaw, 46, 44.

25. William Bradford, History of Plymouth Plantation, 1620-1647, ed. Worthington Chauncey Ford, 2 vols. (New York, 1968), 1:149; John Bunyan, The Life and Death of Mr. Badman, Presented to the World in a Familiar Dialogue Between Mr. Wiseman, and Mr. Attentive, ed. James F. Forrest and Roger Sharrock (Oxford, 1988), 32-33; John Flavel, Navigation Spiritualized; or, A New Compass for Seamen. To which are Added, Serious Warnings against the Sins of Drunkenness, Swearing, Uncleanness, Forgetfulness of Mercies, and Contempt of Death (Hull, 1791), iv; John Jea, "The Life, History, and Unparalleled Sufferings of John Jea, the African Preacher, Compiled and Written by Himself," in Pioneers of the Black Atlantic: Five Slave Narratives from the Enlightenment, 1772-1815, ed. Gates, and William L. Andrews (Washington, 1998), 416.

26. Stonhouse, 5 .

27. For "exclamatory" or "ejaculatory" oaths—oaths "uttered in a single or a few words" - see Montagu, 105.

28. The same principle is expressed in Psalm 109:17: "His Delight was in Cursing, and it shall happen unto him" (Archbishop Sharp's Sermon, 24).

29. As Marcus Rediker notes, it was "a commonplace that seamen were the greatest of cursers and swearers, hence the superlative phrase "with seamanlike profanity'" (Between the Devil and the Deep Blue Sea: Merchant Seamen, Pirates, and the Anglo-American Maritime World, 1700-1750 [Cambridge, 1987], 165).

30. Douglas Anderson, “Division Below the Surface: Olaudah Equiano's Interesting Narrative," Studies in Romanticism 43, no. 3 (2004): 439-60, 455.

31. Eileen Razzari Elrod, "Moses and the Egyptian: Religious Authority in Olaudah Equiano's Interesting Narrative," African American Review 35, no. 3 (2001): 409-25, 419-20.

32. As cited in Wells, 4.

33. A Letter to a Prophane Person, Perswading him to Consider his Dreadful Sin and Danger, and to Betake himself to a New Life (Dublin, 1721), 9.

34. Edmund Gibson, An Admonition against Profane and Common Swearing, 12th ed. (London, 1748), 14.

35. For the relationship between these societies and swearing, and the broader argument that "the roots of modern English attitudes towards bad language lie in the late seventeenth and early eighteenth centuries," see Tony McEnery, Swearing in English: Bad Language, Purity and Power from 1586 to the Present (London, 2006), 2 and passim.

36. The engraving of Bahama Banks - done after a painting by Samuel Atkins—served as frontispiece to the second volume in the two-volume first and second editions; from the fourth edition, it preceded chapter 8 .

37. McEnery, 114.

38. S. E. Ogude, "Facts into Fiction: Equiano's Narrative Reconsidered," Research in African Literatures 13 (Spring 1982): 31-43, 38. While significant in its own right, the division here along racial lines, between the blacks who save lives and the whites who turn to drink, does not detract from the central role assumed by Equiano himself within the narration of this episode.

39. In this emphasis upon the punitive nature of the speech act-and the divine intervention-imagined here, my reading is less celebratory of linguistic performativity than is Molesworth, who writes of this episode that "For Equiano, the Bible not only recounts a history of the world including the acts of the original Apostles; in the proper hands it may produce felicitous actions by new apostles, as he surely fancies himself" (125).

40. Walter F. Pitts, Old Ship of Zion: The Afro-Baptist Ritual in the African Diaspora (New York, 1993), 41. 
41. For a more detailed discussion of magic in Equiano, see Helen Thomas, Romanticism and Slave Narratives: Transatlantic Testimonies (Cambridge, 2000), 232-36. Usefully, Thomas notes the problems, as well as the performance, of Equiano's attempted "fusion" of Igbo and (dissenting) Protestant concepts (233). In Lynn Festa's view, Equiano's focus upon the Bible as material object (as opposed to its spiritual content) in this episode can also be read as "a troubling incursion of idolatry into Protestantism" (Sentimental Figures of Empire in Eighteenth-Century Britain and France [Baltimore, 2006], 142).

42. As Equiano indicates, the Miskito themselves lack indigenous oaths: "Neither had they, as I ever could learn, one word expressive of an oath. The worst word I ever heard amongst them when they were quarreling, was one that they had got from the English, which was, 'you rascal'" (206).

43. Gates, $144,150$.

44. Thomas Wilson, An Essay Towards an Instruction for the Indians: Explaining the Most Essential Doctrines of Christianity (London, 1740), 40.

45. Wilson, 41.

46. William Mottolese, “'Almost an Englishman': Olaudah Equiano and the Colonial Gift of Language," Bucknell Review 41, no. 2 (1998): 160-71, 164-65.

47. [Laurence Harlow], The Conversion of an Indian, in a Letter to a Friend, 3rd ed. ([London], 1778). As Carretta notes in his edition of the Narrative, Equiano's description of this text- "a little book, entitled 'The Conversion of an Indian' . . . in questions and answers" (185) - appears to involve a "conflated reference to both the catechetic form" of Wilson's work and to the "content," and indeed the size, of Harlow's non-catechetic one (289).

48. [Harlow], 4, 5, 13, and passim.

49. On this curse (which, strictly speaking, was a curse upon Canaan), see for instance Keith A. Sandiford, Measuring the Moment: Strategies of Protest in Eighteenth-Century AfroEnglish Writing (Selinsgrove, 1988), 100-101.

50 . On the "bad language" of ship captains and its corrosive impact on their authority, see also Greg Dening, Mr Bligh's Bad Language: Passion, Power and Theatre on the Bounty (Cambridge, 1992), 55-61.

51. Compare Thomas Bradbury, The Sin and Danger of Profane Swearing Expos'd, in Several Sermons (London, 1742), 23: "There is no abomination, that is more contagious. If you cannot cure your Acquaintance of swearing, you are in danger of being infected by them."

52. Appleton, 35.

53. Developing Primo Levi's statement that "we, the survivors, are not the true witnesses," recent theoretical work on testimony has stressed the difficulty, if not the actual impossibility, of witnessing to atrocity (The Drowned and the Saved, trans. Raymond Rosenthal [London, 1989], 63-64). See, for instance, Giorgio Agamben, Remnants of Auschwitz: The Witness and the Archive, trans. Daniel Heller-Roazen (New York, 2002). Some of the problems entailed in arguments for the impossibility of testimony to slavery are revealed by Dwight A. McBride's account of Equiano as an "impossible witness" who nevertheless does manage to witness to what he has seen and experienced in the Americas: Impossible Witnesses: Truth, Abolitionism, and Slave Testimony (New York, 2001), 142. The paradox involved in narrating slavery-in telling a story that cannot be told-is more usefully explored in Sara Salih, "Putting Down Rebellion: Witnessing the Body of the Condemned in Abolition-Era Narratives," in Slavery and the Cultures of Abolition: Essays Marking the Bicentennial of the British Abolition Act of 1807, ed. Brycchan Carey and Peter J. Kitson (Cambridge, 2007), 64-86, 73-74.

54. Carretta, Equiano, The African, 320-22. As Carretta observes, "In effect, Equiano's status claim was also a credibility claim" (322).

55. Bradbury, 33.

56. An Earnest Invitation to all Profane Persons to Repent: or, An Help for Recovery from the Detestable Habit of Profane Swearing and Cursing; with A Special Regard to the Army and Navy, 3rd ed. (Edinburgh, 1757), 26. 